\title{
Analysis of Endoplasmic Reticulum (ER) Stress Induced during Somatic Cell Nuclear Transfer (SCNT) Process in Porcine SCNT Embryos
}

\author{
Hwa-Yeon Lee ${ }^{1}$, Hyo-Kyung Bae ${ }^{1}$, Bae-Dong Jung ${ }^{1}$, Seunghyung Lee², \\ Choon-Keun Park², Boo-Keun Yang ${ }^{2}$, and Hee-Tae Cheong ${ }^{1}$ \\ ${ }^{1}$ College of Veterinary Medicine and Institute of Veterinary Science, Kangwon National University, Chuncheon 24341, Korea \\ ${ }^{2}$ College of Animal Life Sciences, Kangwon National University, Chuncheon 24341, Korea
}

\begin{abstract}
This study investigates the endoplasmic reticulum (ER) stress and subsequent apoptosis in duced during somatic cell nuclear transfer (SCNT) process of porcine SCNT embryos. Porcine SCNT and in vitro fertilization (IVF) embryos were sampled at $3 \mathrm{~h}$ and $20 \mathrm{~h}$ after SCNT or IVF and at the blastocyst stage for mRNA extraction. The $\mathrm{x}$-box binding protein 1 (Xbp1) mRNA and the expressions of ER stress-associated genes were confirmed by RT-PCR or RT-qPCR. Apoptotic gene expression was analyzed by RT-PCR. Before commencing SCNT, somatic cells treated with tunicamycin (TM), an ER stress inducer, confirmed the splicing of Xbp 1 mRNA and increased expressions of ER stress-associated genes. In all the embryonic stages, the SCNT embryos, when compared with the IVF embryos, showed slightly increased expression of spliced Xbp1 (Xbp1s) mRNA and significantly increased expression of ER stress-associated genes $(p<0.05)$. In all stages, apoptotic gene expression was slightly higher in the SCNT embryos, but not significantly different from that of the IVF embryos except for the Bax/Bcl2L1 ratio in the 1-cell stage $(p<0.05)$. The result of this study indicates that excessive ER stress can be induced by the SCNT process, which induce apoptosis of SCNT embryos.
\end{abstract}

Key words : Somatic cell nuclear transfer, Endoplasmic reticulum stress, Apoptosis, In vitro fertilization, Pig

\section{INTRODUCTION}

In developmental biology applications, somatic cell nuclear transfer (SCNT) is an important process for producing cloned animals and specific pluripotent embryos or cells. It is widely used in the production of transgenic animals, xenotransplantation, and animal cloning, but one of the major deficiencies of the technique is the low efficiency of the reprogramming of the SCNT embryos (Onishi et al., 2000). The incomplete nuclear reprogramming of the SCNT embryos leads to epigenetic modification (Vignon et al., 2002), aberrant gene expression (Kang et al., 2001), and abnormal X-chromosome inactivation (Xue et al., 2002; Nolen et al., 2005) resulting in abnormal offspring (Kubota et al., 2000; Vignon et al., 2002).

Several studies have sought to improve the nuclear reprogramming by treating with a DNA methylation agent (Enright et al., 2003), impeding Xist expression from the active X-chromosome (Inoue et al., 2010), and modulating nuclear remodeling (Kwon et al., 2008). However, most of these experimental approaches were suitable only for the in vitro culture of SCNT embryos. The SCNT em-

\footnotetext{
Manuscript received February 26, 2018, Received in revised form March 11, 2018, Accepted March 24, 2018

${ }^{\dagger}$ Corresponding Author : Hee-Tae Cheong, College of Veterinary Medicine, Kangwon National University, Chuncheon 24341, Korea. Tel: +82-33-2508659, E-mail: htcheong@kangwon.ac.kr
}

This is an Open Access article distributed under the terms of the Creative Commons Attribution Non-Commercial License (http:// creative-commons.org/licenses/by-nc/3.0) which permits unrestricted non-commercial use, distribution, and reproduction in any medium, provided the original work is properly cited. 
bryos suffered physical and chemical stresses by manipulation during the SCNT process, including micromanipulation, electrofusion, and activation, which restricted nuclear reprogramming (Hwang et al., 2013). It was reported that SCNT technique could alter the mitochondrial membrane potential and trigger the fluctuation of cytosolic $\mathrm{Ca}^{2+}$ concentration (Spikings et al., 2006). Our previous studies were about the physical and chemical stresses of the oocytes caused by the reactive oxygen species (ROS) released during SCNT (Hwang et al., 2013; Bae et al., 2015). The physical and chemical stresses during SCNT resulted in more ROS being released damaging the mitochondria and DNA (Hwang et al., 2013). Antioxidant treatment during SCNT inhibited the release of ROS thereby reducing cellular damage and enhancing the reprogramming of the SCNT embryos (Bae et al., 2015). Besides ROS, cytoplasmic endoplasmic reticulum (ER) stress can induce cellular damage including apoptosis (Tabas \& Ron, 2001; Groenendyk \& Michalak, 2005; Szegezdi et al., 2006) and mitochondrial dysfunction (Wu et al., 2015), which can affect embryo development (Zhang et al., 2012a; Yoon et al., 2014). The most important functions of the ER are protein synthesis, secretory modification and protein folding into the native conformation. Disturbed ER homeostasis affects proper protein folding and leads to the accumulation of unfolded or misfolded proteins in the ER lumen. When the amount of unfolded proteins exceeds the folding capacity of the ER, it results in ER stress. In this condition, cells activate a defense mechanism called the unfolded protein response (UPR) or ER stress response (Boyce \& Yuan, 2006; Malhotra \& Kaufman, 2007). Malfunction of the ER stress response caused by aging, genetic mutations, or environmental factors can result in several diseases like diabetes, inflammation, and neurodegenerative disorders (Yoshida, 2007).

Alleviation of ER stress reduced apoptosis and enhanced the development of bovine SCNT embryos (Song et al.,
2014). Expression of the ER stress-associated gene and apoptotic gene was high in SCNT blastocysts (Cánepa et al., 2014). ER stress is closely related to the release of ROS (Malhotra et al., 2008; Yoon et al., 2014). As ROS were released during the SCNT process also, they induced ER stress. Therefore, ER stress should be inhibited at the initial step of the SCNT process rather than during the culture period to prevent the ER stress-derived cellular damage. Thus, in this study, we examined the ER stress and subsequent apoptosis in porcine SCNT embryos and compared them with in vitro fertilization (IVF) embryos.

\section{MATERIALS AND METHODS}

\section{Chemicals}

All chemicals and reagents were purchased from SigmaAldrich Chemical Co. (St Louis, Mo, USA) unless otherwise indicated.

\section{Demonstration of ES stress assessment using} somatic cells treated with tunicamycin

Porcine ear skin fibroblast cells were seeded in a 24well plate and cultured in Dulbecco's modified Eagle's medium (DMEM; Gibco, Grand Island, NY, USA) supplemented with $10 \%$ fetal bovine serum (FBS; GenDEPOT, Katy, Texas, USA) and 1\% penicillin and streptomycin $\left(\mathrm{P} / \mathrm{S}\right.$; Nalgene, Manassas, Virginia, USA) at $39^{\circ} \mathrm{C}, 5 \%$ $\mathrm{CO}_{2}$ in air for 3-4 days. To induce ER stress, cells that reached $70-80 \%$ confluence were treated with $2 \mu \mathrm{g} / \mathrm{mL}$ or $5 \mu \mathrm{g} / \mathrm{mL}$ tunicamycin (TM), an ER stress inducer, for $3 \mathrm{~h}$ or $6 \mathrm{~h}$, respectively. The cells were assessed for ER stress after the treatments.

\section{In vitro maturation of oocytes}

Porcine cumulus-oocyte complexes (COCs) were collected from the follicles (3-6 mm diameter) and cultured in $500 \mu \mathrm{L}$ droplets of in vitro maturation (IVM) medium overlaid with paraffin oil at $39^{\circ} \mathrm{C}, 5 \% \mathrm{CO}_{2}$ in air for $42-44$ 
h. The IVM medium was Tissue Culture Medium 199 (TCM199; Gibco) supplemented with $0.1 \%$ polyvinyl alcohol (PVA), $3.05 \mathrm{mM}$ D-glucose, $0.91 \mathrm{mM}$ Na-pyruvate, $75 \mu \mathrm{g} / \mathrm{mL}$ penicillin $\mathrm{G}, 50 \mu \mathrm{g} / \mathrm{mL}$ streptomycin, $0.57 \mathrm{mM}$ cysteine, $10 \mathrm{ng} / \mathrm{mL}$ epidermal growth factor, $0.5 \mu \mathrm{g} / \mathrm{mL}$ luteinizing hormone, and $0.5 \mu \mathrm{g} / \mathrm{mL}$ follicle stimulating hormone.

\section{Preparation of donor cells}

Frozen-thawed porcine ear skin fibroblasts (4-6 passages) were cultured in DMEM (Gibco) supplemented with $15 \% \mathrm{FBS}$ and $1 \% \mathrm{P} / \mathrm{S}$ (Nalgene) at $39^{\circ} \mathrm{C}, 5 \% \mathrm{CO}_{2}$ in air for 6-7 days until they reached confluence to synchronize the cell cycle at the G0/G1 phase. Cells were trypsinized with $0.05 \%$ trypsin-EDTA and centrifuged $(500 \times \mathrm{g}, 5 \mathrm{~min})$ in HEPES-buffered TCM-199 supplemented with 0.78 $\mathrm{mM} \mathrm{NaHCO}_{3}, 0.14 \mathrm{mM}$ penicillin $\mathrm{G}, 0.08 \mathrm{mM}$ streptomycin and $3 \mathrm{mg} / \mathrm{mL}$ BSA (TCM-BSA). Cells were cultured in TCM-BSA containing $10 \mu \mathrm{g} / \mathrm{mL}$ phytohemagglutinin-P (PHA-P) for $10 \mathrm{~min}$ prior to SCNT.

\section{Nuclear transfer}

SCNT was carried out in HEPES-buffered TCM-BSA containing $5 \mu \mathrm{g} / \mathrm{mL}$ cytochalasin B. The cumulus cells of the in vitro matured oocytes were removed by vortexing in PBS supplemented with $0.1 \%(\mathrm{w} / \mathrm{v})$ hyaluronidase and $0.1 \%(\mathrm{w} / \mathrm{v})$ PVA for $3 \mathrm{~min}$. The oocytes were enucleated by removing the MII chromosome mass and the first polar body. Enucleation was confirmed by staining the oocytes with $1 \mu \mathrm{g} / \mathrm{mL}$ Hoechst 33342 at $39^{\circ} \mathrm{C}$ for $15-20 \mathrm{~min}$. About $90 \%$ of the oocytes were enucleated successfully (data not shown). Donor cells were injected into the perivitelline space of the enucleated recipient oocytes.

\section{Electrofusion and activation}

The reconstituted oocytes were manually aligned between two wire electrodes (1-mm apart) of a fusion chamber overlaid with $0.3 \mathrm{M}$ mannitol solution containing 0.1
$\mathrm{mM} \mathrm{MgSO}_{4}, 0.05 \mathrm{mM} \mathrm{CaCl}_{2}$ and $0.5 \mathrm{mM}$ HEPES (Duchefa Biochemie, Haarlem, the Netherlands). For the fusion and activation, two pulses of $1.25 \mathrm{kV} / \mathrm{cm}$ direct-current (DC) were applied for $30 \mu \mathrm{sec}$ each using a BTX Electro Cell Manipulator 200 (BTX, San Diego, CA, USA). After the fusion/activation treatment, the reconstituted oocytes were placed in PZM-3 and checked for fusion.

\section{In vitro fertilization}

For IVF, the in vitro-matured oocytes were separated from the surrounding cumulus cells by gentle pipetting. The oocytes were inseminated with frozen-thawed spermatozoa $\left(3 \times 10^{5}\right.$ spermatozoa $\left./ \mathrm{mL}\right)$ in a $100-\mu \mathrm{L}$ droplet of IVF medium (40 oocytes per droplet) at $39^{\circ} \mathrm{C}, 5 \% \mathrm{CO}_{2}$ in air for $6 \mathrm{~h}$. The IVF medium was based on modified Trisbuffered medium (mTBM) containing $113.1 \mathrm{mM} \mathrm{NaCl}, 3$ $\mathrm{mM} \mathrm{KCl}, 7.5 \mathrm{mM} \mathrm{CaCl}_{2} \cdot \mathrm{H}_{2} \mathrm{O}, 20 \mathrm{mM}$ Trizma, $5 \mathrm{mM}$ pyruvic acid, $0.07 \mathrm{mM} / \mathrm{mL}$ streptomycin sulfate, $11 \mathrm{mM} \mathrm{D}$ glucose, $0.17 \mathrm{mM}$ penicillin-G and $0.7 \mathrm{mM}$ caffeine. After insemination culture, second polar body-extruded embryos were used for in vitro culture.

\section{In vitro culture}

After activation or fertilization, the SCNT and IVF embryos were cultured in PZM-3 medium (Yoshioka et al., 2002) for 6 days at $39^{\circ} \mathrm{C}, 5 \% \mathrm{CO}_{2}$ in air. At $3 \mathrm{~h}, 20 \mathrm{~h}$ and 6 days of culture, the embryos were sampled to analyze the x-box binding protein 1 (Xbp1) mRNA, ER stress-associated genes and apoptotic genes.

\section{RNA isolation and cDNA synthesis}

Total RNA from cells with or without TM treatment was extracted using Trizol (Invitrogen, Carlsbad, CA, USA). Poly(A) mRNAs of the IVF and SCNT embryos at $3 \mathrm{~h}$ and $24 \mathrm{~h}$ (one-cell stage) or 6 days (blastocyst stage) after IVF or fusion were extracted according to the manufacturer's protocol using the Dynabeads mRNA Direct kit (Life Technologies AS, Oslo, Norway). Briefly, each group of 
embryos was sampled in $10 \mu \mathrm{L}$ RNAlater ${ }^{\circledR}$ solution and cryopreserved at $-70^{\circ} \mathrm{C}$ until use. After thawing, $10 \mu \mathrm{L}$ of Dynabeads oligo (dT) was added to each sample at room temperature and hybridized for $2 \mathrm{~min}$, and lysed in $200 \mu \mathrm{L}$ of lysis/binding buffer at room temperature for $2 \mathrm{~min}$. The beads were separated from binding buffer using a Dynal magnetic bar. Poly(A) mRNAs and beads were washed with Buffer A and B and poly(A) mRNA was collected at $63^{\circ} \mathrm{C}$ with $6.5 \mu \mathrm{L}$ of Tris- $\mathrm{HCl}$ buffer. The cDNA synthesis was performed according to the manufacturer's protocol using ReverTra Ace ${ }^{\circledR}$ qPCR RT Master Mix (Toyobo, Osaka, Japan). Six $\mu \mathrm{L}$ of the isolated total RNA or mRNA was denatured at $65^{\circ} \mathrm{C}$ for $5 \mathrm{~min}$. Genomic DNA was removed by adding $2 \mu \mathrm{L}$ of $4 \mathrm{x}$ DN Master Mix to the RNA template and incubating at $4^{\circ} \mathrm{C}$ for $5 \mathrm{~min}$, followed by reverse transcription by adding $2 \mu \mathrm{L}$ of $5 \mathrm{x}$ RT Master Mix and incubating at $37^{\circ} \mathrm{C}$ for $20 \mathrm{~min}$. Secondary RNA structure was denatured by incubating at $50^{\circ} \mathrm{C}$ for $5 \mathrm{~min}$ and the reaction was terminated by incubation at $98^{\circ} \mathrm{C}$ for $5 \mathrm{~min}$. The products were stored at $4^{\circ} \mathrm{C}$ until amplification.

\section{Reverse transcription-polymerase chain reac-} tion (RT-PCR) and real-time quantitative RT-PCR (RT-qPCR)

Expression of Xbp1 mRNA, the key transcription factor in the ER stress condition, and apoptotic gene expression were detected by RT-PCR analysis, and expressions of ER stress-associated genes, the C/EBP homologous protein (CHOP), binding protein (BiP), activating transcription factor 4 (ATF4) and glucose-regulated protein 94 (GRP94) were analyzed by RT-qPCR. For RT-PCR, the cDNA samples were reverse-transcribed according to the manufacturer's instructions using AccuPower ${ }^{\circledR}$ Taq PCR PreMix (Bioneer, Daejeon, Korea). After an initial denaturation step of $1 \mathrm{~min}$ at $72^{\circ} \mathrm{C}, 34$ amplification cycles were performed. Each cycle consisted of denaturation at $95^{\circ} \mathrm{C}$ for $30 \mathrm{sec}$, annealing at $58^{\circ} \mathrm{C}$ for $30 \mathrm{sec}$, and extension at $72^{\circ} \mathrm{C}$ for 50 sec. A final extension step of $5 \mathrm{~min}$ at $72^{\circ} \mathrm{C}$ was performed to complete the reaction. The PCR products were analyzed by UV irradiation with an UV transilluminator (Bio-Rad, Berkeley, CA, USA) on a 2\% agarose gel (Amresco, Cleveland, $\mathrm{OH}, \mathrm{USA}$ ) stained with ethidium bromide (Bioneer). Band intensity was measured by densitometry through ImageJ software $1.37 \mathrm{v}$ (National Institutes of Health, Bethesda, MD, USA). RT-qPCR was performed using the power SYBR Green PCR master Mix (TOPrealTM qPCR 2X PreMIX; SYBR Green with high ROX, Enzynomics, Daejeon, Korea) in a StepOne Plus instrument (Applied Biosystems, Foster City, CA, USA). The comparative CT method ( $\triangle \Delta C T$ method) was used for relative quantification of the mRNA level of each target gene. Glyceraldehyde 3-phosphate dehydrogenase (GAPDH) was used as an internal control for the normalization of target gene expression. Primer pairs synthesized for the primer sequences of each gene are shown in Table 1.

\section{Statistical analysis}

The experiments for each condition were repeated at least five times. Analysis of variance (ANOVA) and Duncan's multiple-range test or student $t$-test using the Statistical Analysis System (SAS) software package (SAS Institute, Cary, NC, USA) were used in data analysis.

\section{RESULTS}

\section{ER stress in TM-treated somatic cells}

Only TM-treated cells, not untreated control cells, showed spliced Xbp1 (Xbp1s) mRNA (Fig. 1A). Xbp1s mRNA against total Xbp1 mRNA was increased in somatic cells treated with $\mathrm{TM}$ in relation to the TM dosage ( 2 or 5 $\mu \mathrm{g} / \mathrm{mL}$ ) and treatment time ( 3 or $6 \mathrm{~h}, p<0.05$ ). ER stressassociated gene (CHOP, BiP ATF4 and GRP94) transcription levels were significantly higher after treatment with 5 $\mu \mathrm{g} / \mathrm{mL}$ TM for $3 \mathrm{~h}$ compared with the corresponding control ( $p<0.05$, Fig. 1B). 
Table 1. All primer sequences used for RT-PCR and RT-qPCR

\begin{tabular}{|c|c|c|c|c|}
\hline Genes & Primer sequence $\left(5^{\prime}-3^{\prime}\right)$ & $\begin{array}{l}\text { Length } \\
\text { (bp) }\end{array}$ & $\begin{array}{l}\text { GenBank } \\
\text { Acc No. }\end{array}$ & $\begin{array}{l}\text { Annealing } \\
\text { temp }\left({ }^{\circ} \mathrm{C}\right)\end{array}$ \\
\hline XBP1 & $\begin{array}{l}\text { F-GGCAGAGACCAAGGGGAATG } \\
\text { R-GGGTCGACTTCTGGGAGCTG }\end{array}$ & 263 & FJ213449.1 & 60 \\
\hline $\mathrm{CHOP}$ & $\begin{array}{l}\text { F-AAGACCCAGGAAACGGAAAC } \\
\text { R-TCCAGGAAAGGTCAGCAGTA }\end{array}$ & 261 & NM_001144845.1 & 58 \\
\hline $\mathrm{BiP}$ & $\begin{array}{l}\text { F-ACCAATGACCAAAATCGCCT } \\
\text { R-GTGACTTTCCAGCCACTCAA }\end{array}$ & 246 & J03214.1 & 58 \\
\hline ATF4 & $\begin{array}{l}\text { F-TGAGCCCTGACTCCTATCTG } \\
\text { R-TCCAGCTCTTTACATTCGCC }\end{array}$ & 277 & NM_001123078.1 & 58 \\
\hline GRP94 & $\begin{array}{l}\text { F-CTGCTGAAGGGGAAGTTACC } \\
\text { R-ATCATCTGAGTCCACAACGC }\end{array}$ & 197 & Y09136.1 & 58 \\
\hline $\mathrm{Bcl} 2 \mathrm{~L} 1$ & $\begin{array}{l}\text { F-GTTGACTTTCTCTCCTACAAGC } \\
\text { R-GGTACCTCAGTTCAAACTCATC }\end{array}$ & 277 & NM_214285.1 & 55 \\
\hline Bax & $\begin{array}{l}\text { F-ACTGGACAGTAACATGGAGC } \\
\text { R-GTCCCAAAGTAGGAGAGGAG }\end{array}$ & 294 & XM003127290.3 & 55 \\
\hline Caspases-3 & $\begin{array}{l}\text { F-GAGGCAGACTTCTTGTATGC } \\
\text { R-CATGGACACAATACATGGAA }\end{array}$ & 237 & NM_214131 & 60 \\
\hline GAPDH & $\begin{array}{l}\text { F-GGGCATGAACCATGAGAAGT } \\
\text { R-AAGCAGGGATGATGTTCTGG }\end{array}$ & 230 & AF017079 & 58 \\
\hline
\end{tabular}

Xbp1, x-box binding protein 1 ; CHOP, homologous protein ; BiP, binding protein; ATF4, activating transcription factor 4; GRP94, glucose-regulated protein 94 ; GAPDH, Glyceraldehyde 3-phosphate dehydrogenase.

\section{ER stress in SCNT and IVF embryos}

All groups of both IVF and SCNT embryos showed Xbp1s mRNA. Xbp1s mRNA expression was strong at $3 \mathrm{~h}$ after fusion/activation or IVF and the 1-cell stage, but weak in the blastocyst stage (Fig. 2, upper panel). Expression level of Xbp1s mRNA against total Xbp1 mRNA in the SCNT embryos was slightly higher in all the embryonic stages compared to IVF embryos, but there was no significant difference between SCNT and IVF embryos within the same stage (Fig. 2). However, ER stress-associated gene (CHOP, BiP ATF4 and GRP94) transcription levels were significantly higher in the SCNT embryos compared to IVF embryos in all the embryonic stages ( $p<0.05$, Fig. 3 ).

\section{Apoptosis in SCNT and IVF embryos}

The ratio of Bax to Bcl2L1 was significantly higher in the 1-cell stage of the SCNT embryos $(p<0.05)$, but no significant differences were observed in the other stages (Fig. 4A). Caspase-3 activity was greater in the SCNT embryos in the early stages, but there were no significant 

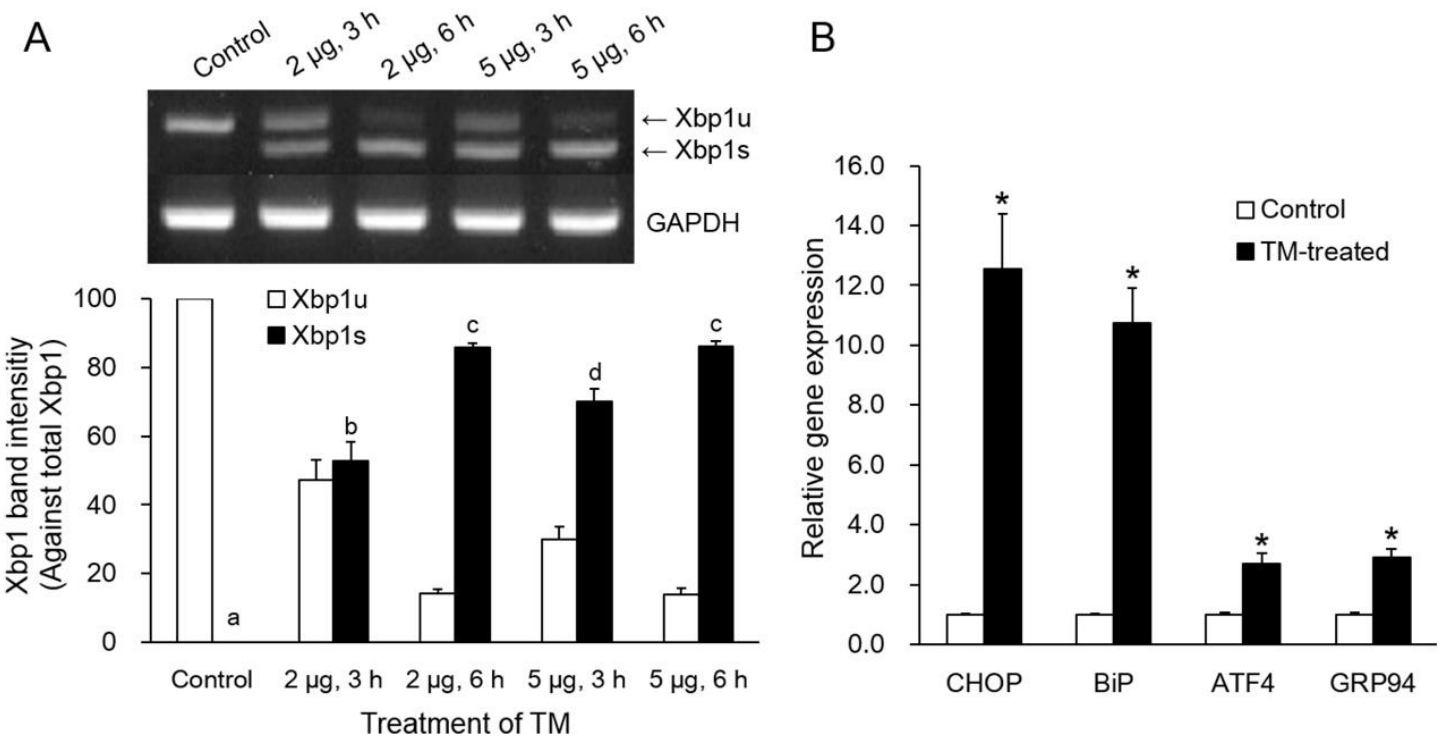

Fig. 1. Induction of ER stress in porcine somatic cells treated with TM. A: Xbp1 mRNA expression. Somatic cells were treated with 2 or $5 \mu \mathrm{g} / \mathrm{mL}$ TM for 3 or $6 \mathrm{~h}$. Spliced and unspliced Xbp1 (Xbp1s and Xbp1u) mRNAs were detected by RT-PCR and band intensity was measured by densitometry. B: ER stress-associated gene expression in somatic cells treated with $5 \mu \mathrm{g} / \mathrm{mL}$ TM for $3 \mathrm{~h}$. ER stress-associated genes were quantified by RT-qPCR. Data are presented as mean \pm SEM. a-d, Values with different letters are significantly different $(p<0.05) .{ }^{*}$ Values are significantly different from each corresponding control $(p<0.05)$. ER, endoplasmic reticulum; TM, tunicamycin; Xbp1, $\mathrm{x}$-box binding protein 1.

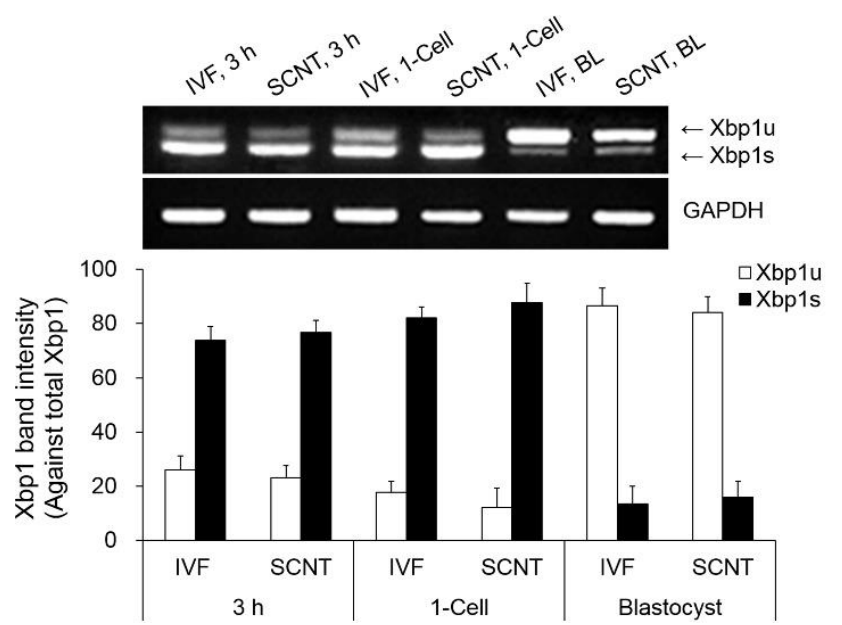

Fig. 2. Xbp1 mRNA expression in porcine somatic cells nuclear transfer and in vitro fertilized embryos. Spliced and unspliced Xbp1 (Xbp1s and Xbplu) mRNAs were detected by RT-PCR at $3 \mathrm{~h}$ after fusion/activation or IVF and the 1-cell and blastocyst stages. Band intensity was measured by densitometry. Data were presented as mean \pm SEM. Xbp1, $\mathrm{x}$ box binding protein 1 ; IVF, in vitro fertilization; SCNT, somatic cell nuclear transfer; BL, blastocyst.

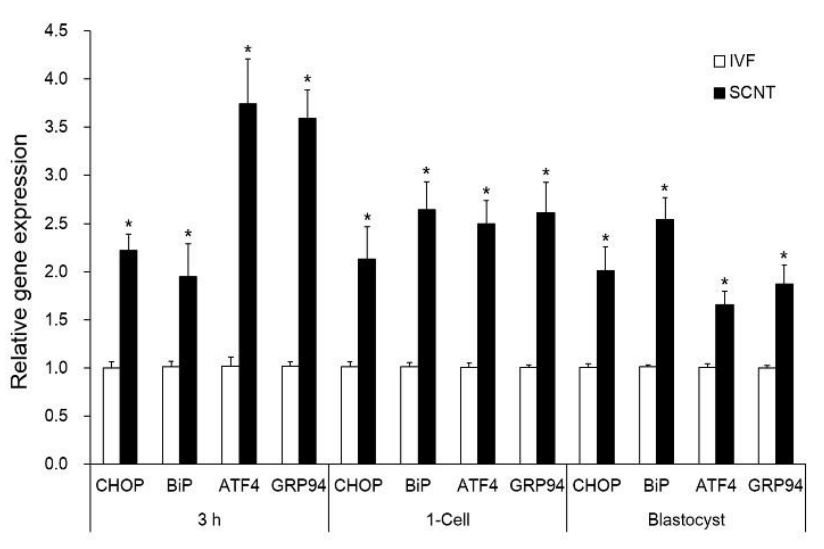

Fig. 3. ER stress-associated gene expression in porcine somatic cells nuclear transfer and in vitro fertilized embryos. ER stress-associated gene expression was quantified by RT-qPCR at $3 \mathrm{~h}$ after fusion/activation or IVF and the 1-cell and blastocyst stages. Data were presented as mean \pm SEM. ${ }^{*}$ Values are significantly different from each corresponding control $(p<0.05)$. IVF, in vitro fertilization, ER, endoplasmic reticulum; SCNT, somatic cell nuclear transfer. 

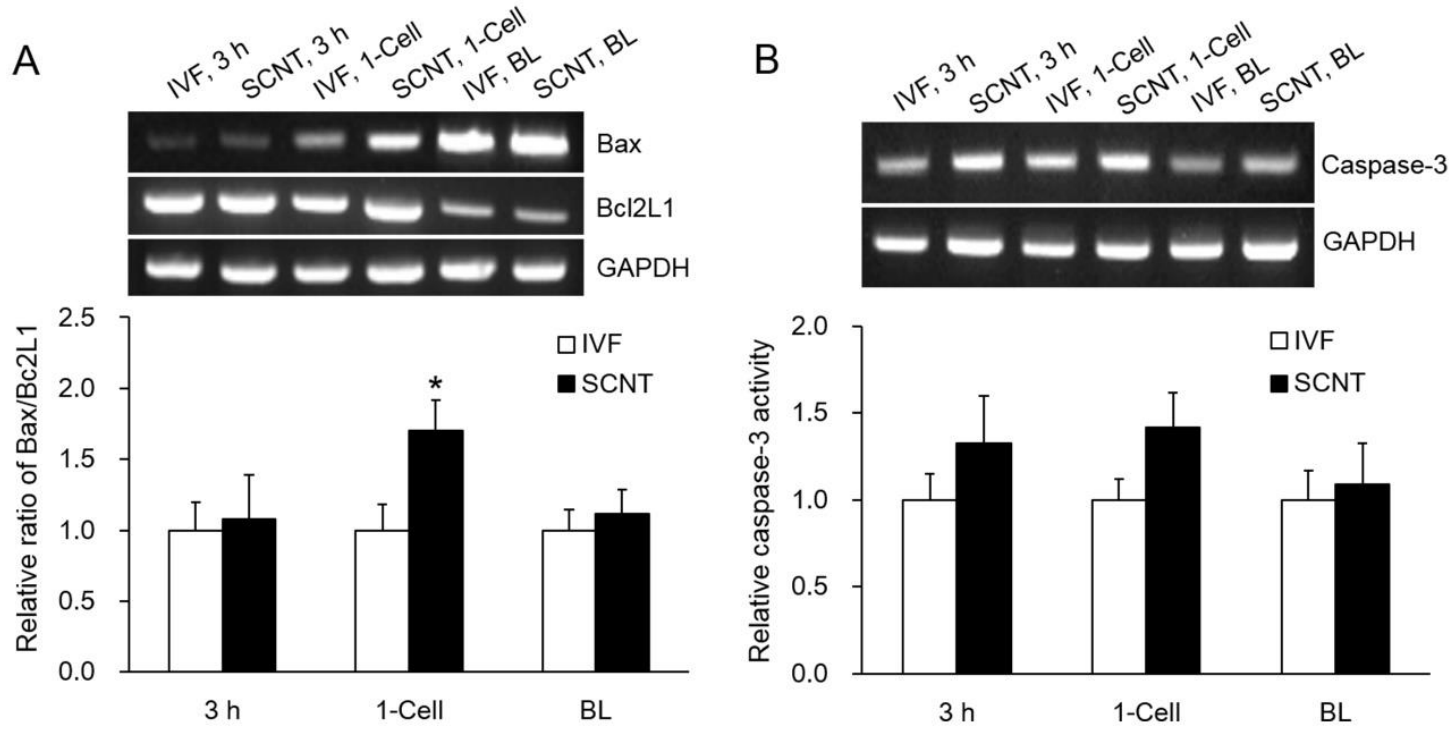

Fig. 4. Apoptotic gene expressions in porcine somatic cells nuclear transfer and in vitro fertilized embryos. A: Relative ratio of Bax to Bcl2L1 mRNA expression. B: Relative Caspase-3 mRNA expression. Apoptotic gene expressions were detected by RT-PCR at $3 \mathrm{~h}$ after fusion/activation or IVF and the 1-cell and blastocyst stages. Band intensity was measured by densitometry. Data were presented as mean \pm SEM. *Value is significantly different from IVF embryos $(p<0.05)$. IVF, in vitro fertilization; SCNT, somatic cell nuclear transfer; BL, blastocyst.

differences across the stages (Fig. 4B).

\section{DISCUSSION}

As unfolded/misfolded proteins continue to accumulate in the ER lumen, UPR is activated to adapt to the ER stress. UPR is important to restore ER homeostasis and reestablish normal ER function. To reduce the accumulation of unfolded/misfolded protein, the UPR signaling sensor/pathway inositol-requiring enzyme 1 (IRE1), PKR-like ER kinase (PERK) and activating transcription factor 6 (ATF6) are activated in the ER luminal domains (Boyce \& Yuan, 2006; Yoshida, 2007). In general, BiP binds to the IRE1, PERK, and ATF6 and is inactive. As unfolded/misfolded proteins accumulate the ER, BiP dissociates from the IRE1, PERK, and ATF6 leading to the activation of UPR (Yoshida, 2007). Upon ER stress, IRE1 phosphorylation is activated through dimerization and unconventional splicing, the unspliced Xbp1 (Xbp1u) mRNA removing a 26base nucleotide intron to cause a subsequent frame shift, and then converting to the Xbp1s (Schröder and Kaufman, 2005; Hetz and Glimcher, 2009). Activation of PERK involves homodimerization and autophosphorylation, leading to phosphorylation of $\alpha$-subunit of eukaryotic translational initiation factor 2 (elf $2 \alpha$ ), which leads to the translation of ATF4 (Fels \& Koumenis, 2006). ATF4 stimulates the expression of CHOP, a key transcription factor for initiating the apoptotic program in extreme ER stress conditions (Nishitoh, 2012). Activated ATF6 is moved to the Golgi apparatus for translocation (Yoshida, 2007). Translocated ATF6 regulates the expression of a number several genes including GRP78, GRP94, XBP1, and CHOP (Yoshida et al., 2001; Adachi et al., 2008; Parmar \& Schröder, 2012). Successful UPR signaling results in embryo/cell survival, whereas the failure to restore ER homeostasis causes cell death.

We confirmed that porcine somatic cells treated with TM showed splicing of Xbp1 mRNA. TM is an antibiotic that inhibits $\mathrm{N}$-glycosylation, which is often essential for protein folding and is usually used to induce ER stress in 
cultured cells (Dorner et al., 1990). Xbp1s mRNA was clearly detected by RT-PCR, and the expression level of Xbpls revealed that the ER stress induced corresponded with TM dosage and treatment time. TM-mediated ER stress induction was also confirmed by ER stress-associated gene expression. These results are consistent with the ER stress analysis in embryos in this study. In previous studies, TM induced ER stress in cells and resulted in increased apoptosis (Boyce \& Yuan, 2006; Zhang et al., 2014). Although, apoptosis did not significantly increase due to TM treatment in this study, ER stress-derived apoptosis could not be fully evaluated because we analyzed the apoptosis following ER stress after treatment with TM for a very short period only (data not shown). On the other hand, the CHOP pathway has been suggested a major regulator of ER stress-induced apoptosis (Zinszner et al., 1998). The strong expression of a pro-apoptotic CHOP, which called the growth arrest and DNA damage inducible gene 153 (GADD153, Price \& Calderwood, 1992) revealed that apoptosis was induced by ER stress. Under the ER stress environment, CHOP stimulates a transcriptional profile that facilitates a pro-apoptotic program and also induces the death receptor 5 (DR5), which sensitizes cells to apoptotic stimulation and may activate Caspase cascades (Yamaguchi \& Wang, 2004).

Xbp1s mRNA was stage-dependently detected at the various developmental stages of porcine parthenogenetic embryos showing different expression levels (Zhang et al., 2012b). ER stress-induced Xbp1 splicing has been implicated in the regulation of early porcine embryonic genome activation (Zhang et al., 2012b). Marginal ER stress may be essential for embryonic development but in excess may induce apoptosis and cell death (Yoshida, 2007). In this study, Xbp1s mRNA was successfully detected in the SCNT and IVF embryos at the early stage and blastocyst stage. Interestingly, there was no difference in Xbp1s mRNA expression levels between the SCNT and IVF embryos, although slightly increased Xbp1s mRNA levels against total
Xbp1 mRNA were observed in SCNT embryos in this study. The quantification of Xbp1 mRNA expression level may not be accurate because we measured the band intensity of the RT-PCR products using densitometry. In a previous study, semiquantitative PCR method was used for the quantification of Xbp1 mRNA expression and the relative transcription levels of $\mathrm{Xbp} 1 \mathrm{~s}$ to total $\mathrm{Xbp} 1$ were significantly higher in the SCNT blastocysts compared with the IVF embryos (Song et al., 2014). Unlike Xbp1s mRNA expression, ER stress-associated genes, such as CHOP, ATF4, BiP, and GRP94, quantified by RT-qPCR were highly expressed in the SCNT embryos compared with the IVF embryos across all stages. ER stress-associated genes were highly expressed at $3 \mathrm{~h}$ immediately after SCNT and the 1cell stage as well as in the blastocyst stage, suggesting that SCNT process induced ER stress in SCNT embryos.

It was demonstrated that ER stress-induced apoptosis was associated with the Caspase-3 (Groenendyk \& Michalak, 2005) and Bcl-2 family protein (Szegezdi et al., 2006). Prolonged UPR induces expression of Caspase-3 and Bcl2 family proteins resulting in apoptosis (Tabas \& Ron, 2001; Gorman et al., 2012). In this study, the ratio of Bax to Bcl2L1 was higher only at the 1-cell stage of the SCNT embryos, and there was no difference in the Caspase- 3 mRNA levels between the SCNT and IVF embryos. However, as in TM-treated somatic cells, sustained elevation of pro-apoptotic CHOP expression in the SCNT embryos revealed that apoptosis was aggravated by the SCNT process. On the other hand, in previous studies on porcine or bovine SCNT embryos, apoptosis was greater in the SCNT embryos compared with IVF or in vivo-derived blastocysts (Hao et al., 2003; Cánepa et al., 2014; Song et al., 2014). In our previous studies too, DNA fragmentation in the 1cell stage of the SCNT embryos (Hwang et al., 2013; Bae et al., 2015) and apoptotic cells in the SCNT blastocysts by TUNEL assay were greater compared to IVF embryos (Bae et al., 2015).

In conclusion, the results of this study confirm that por- 
cine SCNT process induced excessive ER stress and could lead to ER stress-induced apoptosis.

\section{ACKNOWLEDGEMENTS}

This study was supported by Basic Science Research Program through the National Research Foundation of Korea (NRF) funded by the Ministry of Education (2016R 1D1A1B03930662).

\section{REFERENCES}

Adachi Y, Yamamoto K, Okada T, Yoshida H, Harada A, Mori K (2008) ATF6 is a transcription factor specializing in the regulation of quality control proteins in the endoplasmic reticulum. Cell Struct Funct 33:75-89.

Bae HK, Hwang IS, Kim JY, Lee SY, Park CK, Yang BK, Cheong HT (2015) Antioxidant treatment during manipulation process prevents mitochondrial and DNA damage and enhances nuclear reprogramming of bovine somatic cell nuclear transfer embryos. Reprod Fertil Dev 27:1088-1095.

Boyce M, Yuan J (2006) Cellular response to endoplasmic reticulum stress: A matter of life or death. Cell Death Differ 13:363-373.

Cánepa MJ, Ortega NM, Monteleone MC, Mucci N, Kaiser GG, Brocco M, Mutto A (2014) Expression profile of genes as indicators of developmental competence and quality of in vitro fertilization and somatic cell nuclear transfer bovine embryos. PLoS One 9:e108139.

Dorner AJ, Wasley LC, Raney P, Haugejorden S, Green M, Kaufman RJ (1990) The stress response in Chinese hamster ovary cells. Regulation of ERp72 and protein disulfide isomerase expression and secretion. J Biol Chem 265:22029-22034.

Enright BP, Kubota C, Yang X, Tian XC (2003) Epigenetic characteristics and development of embryos cloned from donor cells treated by trichostatin A or 5-aza-20- deoxycytidine. Biol Reprod 69:896-901.

Fels DR, Koumenis C (2006) The PERK/eIF2alpha/ATF4 module of the UPR in hypoxia resistance and tumor growth. Cancer Biol Therapy 5:723-728.

Gorman AM, Healy SJ, Jäger R, Samali A (2012) Stress management at the ER: Regulators of ER stress-induced apoptosis. Pharmacol Ther 134:306-316.

Groenendyk J, Michalak M (2005) Endoplasmic reticulum quality control and apoptosis. Acta Biochim Pol 52: 381-395.

Hao Y, Lai L, Mao J, Im GS, Bonk A, Prather RS (2003) Apoptosis and in vitro development of preimplantation porcine embryos derived in vitro or by nuclear transfer. Biol Reprod 69:501-507.

Hetz C, Glimcher LH (2009) Fine-tuning of the unfolded protein response: Assembling the IRE1 $\alpha$ interactome. Mol Cell 35:551-561.

Hwang IS, Bae HK, Cheong HT (2013) Mitochondrial and DNA damage in bovine somatic cell nuclear transfer embryos. J Vet Sci 14:235-240.

Inoue K, Kohda T, Sugimoto M, Sado T, Ogonuki N, Matoba S, Shiura H, Ikeda R, Mochida K, Fujii T, Sawai K, Otte AP, Tian XC, Yang X, Ishino F, Abe K, Ogura A (2010) Impeding Xist expression from the active $\mathrm{X}$ chromosome improves mouse somatic cell nuclear transfer. Science 330:496-499.

Kang YK, Koo DB, Park JS, Choi YH, Chung AS, Lee KK, Han YM (2001) Aberrant methylation of donor genome in cloned bovine embryos. Nat Genet 28:173177.

Kubota C, Yamakuchi H, Todoroki J, Mizoshita K, Tabara N, Barber M, Yang X (2000) Six cloned calves produced from adult fibroblast cells after long-term culture. Proc Natl Acad Sci 97:990-995.

Kwon DJ, Park CK, Yang BK, Cheong HT (2008) Control of nuclear remodelling and subsequent in vitro development and methylation status of porcine nuclear transfer embryos. Reproduction 135:649-656. 
Malhotra JD, Kaufman RJ (2007) The endoplasmic reticulum and the unfolded protein response. Semin Cell Dev Biol 18:716-731.

Malhotra JD, Miao H, Zhang K, Wolfson A, Pennathur S, Pipe SW, Kaufman RJ (2008) Antioxidants reduce endoplasmic reticulum stress and improve protein secretion. Proc Natl Acad Sci 105:18525-18530.

Nishitoh H (2012) CHOP is a multifunctional transcription factor in the ER stress response. J Biochem 151:217219.

Nolen LD, Gao S, Han Z, Mann MRW, Chung YG, Otte AP, Bartolomei MS, Latham KE (2005) X chromosome reactivation and regulation in cloned embryos. Dev Biol 279:525-540.

Onishi A, Iwamoto M, Akita T, Mikawa S, Takeda K, Awata T, Hanada H, Perry AC (2000) Pig cloning by microinjection of fetal fibroblast nuclei. Science 289: 1188-1190.

Parmar VM, Schröder M (2012) Sensing endoplasmic reticulum stress. Adv Exp Med Biol 738:153-168.

Price BD, Calderwood SK (1992) Gadd45 and gadd153 messenger RNA levels are increased during hypoxia and after exposure of cells to agents which elevate the levels of the glucose-regulated proteins. Cancer Res 52:3814-3817.

Schröder M, Kaufman R (2005) ER stress and the unfolded protein response. Mutat Res 569:29-63.

Song BS, Yoon SB, Sim BW, Kim YH1, Cha JJ, Choi SA, Jeong KJ, Kim JS, Huh JW, Lee SR, Kim SH, Kim SU, Chang KT (2014) Valproic acid enhances early development of bovine somatic cell nuclear transfer embryos by alleviating endoplasmic reticulum stress. Reprod Fertil Dev 26:432-440.

Spikings EC, Alderson J, St John J (2006) Transmission of mitochondrial DNA following assisted reproduction and nuclear transfer. Hum Reprod Update 12:401-415.

Szegezdi E, Logue SE, Gorman AM, Samali A (2006) Mediators of endoplasmic reticulum stress-induced apop- tosis. EMBO Reports 7:880-885.

Tabas I, Ron D (2001) Integrating the mechanisms of apoptosis induced by endoplasmic reticulum stress. Nature Cell Biol 13:184-190.

Vignon X, Zhou Q, Renard JP (2002) Chromatin as a regulative architecture of the early developmental functions of mammalian embryos after fertilization and nuclear transfer. Cloning Stem Cells 4:363-377.

Wu LL, Russell DL, Wong SL, Chen M, Tsai T, St John JC, Norman RJ, Febbraio MA, Carroll J, Robker RL (2015) Mitochondrial dysfunction in oocytes of obese mothers: Transmission to offspring and reversal by pharmacological endoplasmic reticulum stress inhibitors. Development 142:681-691.

Xue F, Tian XC, Du F, Kubota C, Taneja M, Dinnyes A, Dai Y, Levine H, Pereira LV, Yang X (2002) Aberrant patterns of $\mathrm{X}$ chromosome inactivation in bovine clones. Nat Genet 31:216-220.

Yamaguchi H, Wang HG (2004) CHOP is involved in endoplasmic reticulum stress-induced apoptosis by enhancing DR5 expression in human carcinoma cells. J Biol Chem 279:45495-5502.

Yoon SB, Choi SA, Sim BW, Kim JS, Mun SE, Jeong PS, Yang HJ, Lee Y, Park YH, Song BS, Kim YH, Jeong KJ, Huh JW, Lee SR, Kim SU, Chang KT (2014) Developmental competence of bovine early embryos depends on the coupled response between oxidative and endoplasmic reticulum stress. Biol Reprod 90:104, 1-10.

Yoshida H (2007) ER stress and diseases. FEBS J 274: 630-658.

Yoshida H, Matsui T, Yamamoto A, Okada T, Mori K (2001) XBP1 mRNA is induced by ATF6 and spliced by IRE1 in response to ER stress to produce a highly active transcription factor. Cell 107:881-891.

Yoshioka K, Suzuki C, Tanaka A, Anas IM, Iwamura S (2002) Birth of piglets derived from porcine zygotes cultured in a chemically defined medium. Biol Reprod 66:112-119. 
Zhang JY, Diao YF, Kim HR, Jin DI (2012a) Inhibition of endoplasmic reticulum stress improves mouse embryo development. PLoS One 7:e40433.

Zhang JY, Diao YF, Oqani RK, Han RX, Jin DI (2012b) Effect of endoplasmic reticulum stress on porcine oocyte maturation and parthenogenetic embryonic development in vitro. BMC Mol Biol 86:128, 1-9.

Zhang X, Yuan Y, Jiang L, Zhang J, Gao J, Shen Z, Zheng Y, Deng T, Yan H, Li W, Hou WW, Lu J, Shen Y, Dai H, Hu WW, Zhang Z, Chen Z (2014) Endoplasmic re- ticulum stress induced by tunicamycin and thapsigargin protects against transient ischemic brain injury : Involvement of PARK2-dependent mitophagy. Autophagy 10:1801-1813.

Zinszner H, Kuroda M, Wang X, Batchvarova N, Lightfoot RT, Remotti H, Stevens JL, Ron D (1998) CHOP is implicated in programmed cell death in response to impaired function of the endoplasmic reticulum. Genes Dev 12:982-995. 